DOI: https://doi.org/10.15407/techned2019.06.081

\title{
FIBER OPTICAL SENSOR FOR LINEAR MEASUREMENTS
}

Journal

Publisher

ISSN

Issue

Pages
Tekhnichna elektrodynamika

Institute of Electrodynamics National Academy of Science of Ukraine 1607-7970 (print), 2218-1903 (online)

No 6, 2019 (November/December)

$81-87$

\section{Authors}

\section{I.O. Bragynets ${ }^{\star}$, Yu.O. Masjurenko**}

Institute of Electrodynamics National Academy of Sciences of Ukraine, pr. Peremohy, 56, Kyiv, 03057, Ukraine, e-mail: masjuriy@ied.org.ua

* ORCID ID : http://orcid.org/0000-0002-9528-5808

** ORCID ID : http://orcid.org/0000-0003-4209-1126

\section{Abstract}

A simple-designed sensor circuit for contactless stationary linear measurements with optical fibers as light guide is proposed. The scheme of the sensor allows doing constructively the sensor head from optical fiber in the form of a measuring probe. Its will provide an opportunity to carry out express control of the position of the controlled object in space. Taking into account the parameters of the optical elements of the proposed sensor, a lightenergy calculation of the optical circuit was performed. The signal-to-noise ratio at the photodetector output was estimated. A frequency-phase method for processing of an output photodetector signals when measuring the distance to the object being monitored and estimating its position in space was selected and substantiated for the proposed sensor circuit. Analytical modeling of conversion processes in the frequency-phase system was carried out. It's confirmed the possibility of measuring the air gap in the hydrogenerator between the rotor and the stator using the proposed fiber-optic sensor. References 15, figure 1.

Key words: laser, optical fiber, scattered light, diffuse reflection, linear frequency modulation, spectral analysis. 
Received: 20.05.2019

Accepted: 07.06.2019

Published: 25.10.2019

\section{References}

1. Laser triangulation distance sensors. General information. URL: http://www.promsat.com//c ontent/files/cat/prizma/LS5.pdf

(Accessed at 14.02.2019). (Rus)

2. Laser Triangulation Sensor - RF603. URL: http://www.sensorika.com/ru/lazernye-triangulyat sionnye-datchiki/rf603/

(Accessed at

14.02.2019). (Rus)

3. Contactless measuring system based on laser radar series MV300 from 02.2017. URL: http s://nevatec.ru/wp-content/uploads/2017/03/mv300.pdf

(Accessed at 15.05.2019). (Rus)

4. Okosi T., Okamoto K., Otsu M., Nisikhara Kh., Kuma K., Khatate K. Fiber Optic Sensors.

Leningrad: Energoatomizdat, Leningradskoe otdelenie, 1990. 256 p. (Rus)

5. Udd Eric, Spillman William. Fiber optic sensors an Introduction for Engineers and Scientists, John Wiley \& Sons, Inc., 2011. 506 p. DOI: https://doi.org/10.1002/9781118014103

6. Bragynets I.O., Kononenko O.G., Masjurenko Yu.O. Analytical review and selection of optical laser systems for measuring air gaps in powerful hydrogenerators. Pratsi Instytutu Elektrodynamiky Natsionalnoi Akademii Nauk Ukrainy

. 2018. No 49. Pp. 103-110. (Ukr)

DOI:

https://doi.org/10.15407/publishing2018.49.103

7. Cozannet A., Fleuret J., Maitre H., Rousseau M. Optics and communications: Optical transmission and processing of information. Moskva: Mir, 1984. 504 p. (Rus)

8. Parvulusov Yu.B., Soldatov V.P., Yakushenkov Yu.G. Designing of optical-electronic devices: A manual for students of technical colleges. Moskva: Mashinostroenie, 1990. 432 p. (Rus)

9. Legkyi V.N., Galun B.V., Sankov O.V. Optoelectronic elements and devices for special-purpose systems. Novosibirsk: Izdatelstvo NGTU, 2011. 455 p. (Rus)

10. Baranochnikov M.L. Receivers and radiation detectors. Part 2: Receivers of optical radiation. Moskva: DMK Press, 2017. 586 p.

11. Gauer G. Optical communication systems. Moskva: Radio i sviaz, 1989. 504 p. (Rus)

12. Zaitsev E.A., Kononenko A.G., Masjurenko Yu.A., Nizhenskyi A.D., Latenko V.I., Ornatskyi I.A. Special features of a phase-frequency method application in a laser ranging. Tekhnichna Elektrodynamika

. 2008. No 6. Pp. 65-70. (Rus) 
13. Bragynets I.O., Kononenko O.G., Masjurenko Yu.O. Application of the frequency-phase method for controlling the geometric parameters of objects. Tekhnichna Elektrodynamika. 2017. No 6. Pp. 88-93. (Ukr)

DOI:

https://doi.org/10.15407/techned2017.06.088

14. Van Trees Harry L. Detection, Estimation, and Modulation Theory. Part 1: Detection, Estimation, and Linear Modulation Theory. John Wiley \& Sons, Inc., 2001. 690 p. DOI: https://d oi.org/10.1002/0471221090

15. Vygodskyi M.Ya. Handbook of higher mathematics. Moskva: Gosudarstvennoe izdanie fiziko-matematicheskoi literatury, 1958. 784 p. (Rus)

PDF 